SILVA, Leonardo dos Santos; SIMINI, Danilo Garnica. Liberdade de culto e seus eventuais excessos: o exemplo da cidade de Ituverava/SP. Revista Eletrônica Direito e Política, Programa de PósGraduação Stricto Sensu em Ciência Jurídica da UNIVALI, Itajaí, v.12, n.3, $3^{\circ}$ quadrimestre de 2017. Disponível em: www.univali.br/direitoepolitica - ISSN 1980-7791

\title{
LIBERDADE DE CULTO E SEUS EVENTUAIS EXCESSOS: O EXEMPLO DA CIDADE DE ITUVERAVA/SP ${ }^{1}$
}

\author{
LIBERTY OF CULTURE AND ITS EXCESSIVE EVENTS: THE EXAMPLE FROM \\ ITUVERAVA/SP
}

\section{Leonardo dos Santos Silva² \\ Danilo Garnica Simini ${ }^{3}$}

SUMÁRIO: Introdução; 1 Considerações acerca da liberdade de culto e o direito ao sossego; 2 Responsabilidade civil das instituições religiosas; 3 Análise da liberdade de culto e eventuais excessos na realidade de Ituverava; Considerações finais; Referência das fontes citadas

\section{RESUMO}

A Constituição Federal de 1988 determina que o Estado brasileiro é laico e este não deve interferir em qualquer religião, conferindo efetividade à liberdade de culto. Porém, o exercício da liberdade de culto pode trazer violações à direitos, tais como o direito ao sossego, em razão do excesso de som produzido pelas instituições religiosas. O presente trabalho apresenta considerações sobre os excessos decorrentes da liberdade de culto, especialmente, os relacionados aos ruídos produzidos durantes as missas, celebrações e louvores. Inicialmente, o trabalho discute a temática dos direitos fundamentais, bem como a liberdade de culto e o direito ao sossego. Após tal discussão, o trabalho tece algumas considerações importantes acerca da responsabilidade civil das instituições religiosas e por fim realiza um estudo na cidade de Ituverava a fim de que se verifique se encontramos ou não abusos no que diz respeito à liberdade de culto produzidos pelo excesso de ruído durante as celebrações.

PALAVRAS-CHAVE: Liberdade de culto; Direito ao sossego; Ituverava

\section{ABSTRACT}

The Federal Constitution of 1988 states that the Brazilian State is secular and it must not interfere in any religion, giving effectiveness to freedom of worship. But the freedom of worship can bring violations of rights such as the right to peace, because of the sound produced by the excess of sound of religious institutions. This paper presents considerations about the excesses stemming from the freedom

1 O presente artigo corresponde a uma versão resumida do Trabalho de Conclusão de Curso, apresentado no ano de 2016, pelo autor Leonardo dos Santos Silva, orientado pelo autor Professor Ms. Danilo Garnica Simini, junto à Faculdade Francisco Maeda (FAFRAM) de Ituverava/SP, para fins de obtenção do grau de Bacharel em Direito.

\footnotetext{
2 Bacharel em Direito pela Faculdade Francisco Maeda de Ituverava/SP

${ }^{3}$ Doutorando em Ciências Humanas e Sociais (UFABC), Mestre em Direito (UNESP), advogado e docente na Universidade de Ribeirão Preto/SP (UNAERP)
} 
SILVA, Leonardo dos Santos; SIMINI, Danilo Garnica. Liberdade de culto e seus eventuais excessos: o exemplo da cidade de Ituverava/SP. Revista Eletrônica Direito e Política, Programa de PósGraduação Stricto Sensu em Ciência Jurídica da UNIVALI, Itajaí, v.12, n.3, $3^{\circ}$ quadrimestre de 2017. Disponível em: www.univali.br/direitoepolitica - ISSN 1980-7791

of worship, especially those related to noise produced during celebrations and worship. Initially, the paper discusses the issue of fundamental rights and freedom of worship and the right to peace. After this discussion, the paper presents some important considerations about the civil responsibility of religious institutions and finally leads to a study in the city of Ituverava to check if occurs any kind of abuse concerning to freedom of worship, produced by excess noise during the celebrations.

KEYWORDS: Freedom of worship; Right to peace; Ituverava

\section{INTRODUÇÃO}

A Constituição Federal de 1988 determina que o Estado brasileiro é laico, ou seja, não deve adotar uma religião oficial, bem como não poderá interferir nas crenças e religiosidades das pessoas que compõem a sociedade brasileira. Trata-se da garantia da liberdade de culto por meio da qual todo ser humano é livre para professar a sua fé de acordo com suas opiniões e posicionamentos. Contudo, nenhum direito ou liberdade é absoluto, nem mesmo a liberdade de culto.

O cotidiano demonstra que muitas vezes as instituições religiosas em suas missas, louvores, pregações e celebrações acabam de certa forma abusando da liberdade de culto, violando o denominado direito ao sossego, já que o som produzido pelas organizações religiosas muitas vezes não obedece aos limites estabelecidos pela legislação pertinente.

Sendo assim, o presente trabalho visa discutir os excessos decorrentes da liberdade de culto à luz do Direito, notadamente, os excessos relacionados com os ruídos produzidos pelas igrejas em suas celebrações, ruídos que podem violar o direito ao sossego dos indivíduos da comunidade, principalmente, os que residem perto das mesmas.

O trabalho está dividido em três partes. Na primeira discute-se a liberdade de culto e o direito ao sossego. Trata-se de um tópico cujo objetivo é apresentar ao leitor de que forma a liberdade de culto e o direito ao sossego devem ser interpretados no ordenamento jurídico brasileiro. Na segunda parte discute-se a responsabilidade civil das instituições religiosas, tecendo-se algumas considerações gerais acerca do tema, bem como apresentando-se de que forma a jurisprudência vem enfrentando a questão. Por fim, no terceiro tópico foi realizado 
SILVA, Leonardo dos Santos; SIMINI, Danilo Garnica. Liberdade de culto e seus eventuais excessos: o exemplo da cidade de Ituverava/SP. Revista Eletrônica Direito e Política, Programa de PósGraduação Stricto Sensu em Ciência Jurídica da UNIVALI, Itajaí, v.12, n.3, $3^{\circ}$ quadrimestre de 2017. Disponível em: www.univali.br/direitoepolitica - ISSN 1980-7791

um estudo de caso envolvendo a cidade de Ituverava, discutindo-se as leis municipais que tratam do tema, possíveis processos existentes e entrevistas com moradores vizinhos as instituições religiosas.

\section{CONSIDERAÇões ACERCA DA LIBERDADE DE CULTO E O DIREITO AO SOSSEGO}

A Constituição de 1891 estabeleceu os princípios da liberdade religiosa, sendo que estes mesmos princípios permanecem na atual Constituição de 1988, havendo poucos ajustes. Tal liberdade foi legalizada por Ruy Barbosa com o Decreto 119-A de 1890, que veio a se tornar norma constitucional em 1891.

A liberdade religiosa e também de culto está assegurada pelo artigo 50, inciso VI, da Constituição Federal de 1988, complementado com os incisos VII e VIII, a saber.

Art 50. [...]

VI - é inviolável a liberdade de consciência e de crença, sendo assegurado o livre exercício dos cultos religiosos e garantida, na forma da lei, a proteção aos locais de culto e a suas liturgias;

VII - é assegurada, nos termos da lei, a prestação de assistência religiosa nas entidades civis e militares de internação coletiva;

VIII - ninguém será privado de direitos por motivo de crença religiosa ou de convicção filosófica ou política, salvo se as invocar para eximir-se de obrigação legal a todos imposta e recusar-se a cumprir prestação alternativa, fixada em lei;

Os artigos 19, inciso I e 150, inciso VI, alínea "b", ambos da Constituição Federal de 1988 também tratam do tema. O primeiro proíbe a União, os Estados, o Distrito Federal e os Municípios de estabelecer cultos religiosos ou igrejas, subvencionalos, dificultar o seu funcionamento ou manter com eles ou seus representantes, relações de dependência ou aliança, ressalvada, na forma da lei, a colaboração de interesse público. O segundo dispositivo trata da chamada imunidade tributária religiosa que proíbe os entes políticos de instituir impostos de qualquer tipo. 
SILVA, Leonardo dos Santos; SIMINI, Danilo Garnica. Liberdade de culto e seus eventuais excessos: o exemplo da cidade de Ituverava/SP. Revista Eletrônica Direito e Política, Programa de PósGraduação Stricto Sensu em Ciência Jurídica da UNIVALI, Itajaí, v.12, n.3, $3^{\circ}$ quadrimestre de 2017. Disponível em: www.univali.br/direitoepolitica - ISSN 1980-7791

Dentro da liberdade de religião temos três formas de expressão, sendo, liberdade de crença, liberdade de culto e liberdade de organização religiosa. José Afonso da Silva $^{4}$ anota que a liberdade de crença e a de consciência não se confundem, pois o descrente também tem liberdade de consciência, entendendo o autor que pode tanto se ter liberdade de crença quanto não ter.

$\mathrm{Na}$ liberdade de crença entra a liberdade de escolha da religião, a liberdade de aderir a qualquer seita religiosa, a liberdade ou o direito de mudar de religião, mas também compreende a liberdade de não aderir a religião alguma, assim com a liberdade de descrença, a liberdade de ser ateu e de exprimir o agnosticismo ${ }^{5}$.

De qualquer forma, a denominada liberdade de culto deve ser respeitada em um Estado Democrático de Direito, já que o Estado por ser laico deve respeitar todas as manifestações religiosas. Porém, a liberdade de culto não é absoluta, devendo as instituições religiosas respeitar os direitos alheios, entre eles o denominado direito ao sossego, objeto de estudo no próximo tópico, já que nenhum direito é absoluto.

O direito ao sossego, por sua vez, está ligado ao direito à privacidade e ao direito à intimidade, direitos previstos no artigo 50, incisos X e XI, da Constituição Federal de 1988. O direito à privacidade também está ligado à paz e ao equilíbrio do indivíduo e também à sua saúde mental, visando fornecer um ambiente de tranquilidade emocional, para que assim consiga fazer uma auto avaliação de suas metas e objetivos pessoais.

O direito ao sossego é um direito de negação que cessa a ação dos outros, para assim garantir a tranquilidade das pessoas, sendo sagrado, para garantir uma boa qualidade de vida, bem como para que o indivíduo possa impor o término de ruídos que prejudiquem seu direito. O direito ao sossego também decorre do direito de vizinhança e da garantia de um meio ambiente equilibrado. Toda pessoa tem o

\footnotetext{
${ }^{4}$ SILVA, José Afonso da. Comentário contextual à Constituição. 4. ed. São Paulo: Malheiros, 2007.

${ }^{5}$ SILVA, José Afonso da. Comentário contextual à Constituição. p. 94.
} 
SILVA, Leonardo dos Santos; SIMINI, Danilo Garnica. Liberdade de culto e seus eventuais excessos: o exemplo da cidade de Ituverava/SP. Revista Eletrônica Direito e Política, Programa de PósGraduação Stricto Sensu em Ciência Jurídica da UNIVALI, Itajaí, v.12, n.3, $3^{\circ}$ quadrimestre de 2017. Disponível em: www.univali.br/direitoepolitica - ISSN 1980-7791

direito ao sossego e sua transgressão acarreta responsabilização jurídica na esfera civil, criminal e ambiental. ${ }^{6}$

Todo homem tem direito à tranquilidade, no ambiente social em que vive, livre de incômodos descabidos, de achincalhe e de tantas perturbações semelhantes. É bem verdade que no mundo conturbado de hoje tal direito está cada vez mais afastado do ponto considerado ideal. A mecanização do homem, as grandes concentrações populacionais e outros fatores provocados pelo progresso descontrolado, fazendo com que o desrespeito, a falta de cortesia, a má educação se tornem uma constante. Mas nem por isso a prática de atos definidos no art. 65 da Lei das Contravenções Penais deixam de configurar uma infração punível. Pelo contrário: o dispositivo legal visa garantir a tranquilidade pessoal, cada vez mais difícil de ser obtida. ${ }^{7}$

A Lei de Crimes Ambientais (Lei no 9.605/98) trata do assunto em seu artigo 54, cuja redação enuncia que causar poluição de qualquer natureza em níveis tais que resultem ou possam resultar em danos à saúde humana, ou que provoquem a mortandade de animais ou a destruição significativa da flora constitui crime, punível com reclusão, de um a quatro anos, e multa. Havendo comprovação de que o barulho é ofensivo a parte lesada poderá ajuizar ação para que o incômodo cesse, bem como poderá ajuizar ação de responsabilidade por danos morais e patrimoniais causados ao meio ambiente (Lei 7.347/85). Por fim, é cabível ação de tutela inibitória além da chamada ação de dano infecto, nos termos do artigo 1.277 do Código Civil.

Conforme Venosa:

A ação de dano infecto encontra sua estrutura também nos arts. 554 e 555 do Código anterior. 0 art. 1277 é genérico e diz respeito a qualquer nocividade ocasionada ao vizinho. 0 art. 1280 é exclusivo da relação edilícia. Essas situações têm por pressuposto a futuridade de um dano. Dano iminente. Não o dano já ocorrido, mas a possibilidade e potencialidade de vir a ocorrer. ${ }^{8}$

\footnotetext{
${ }^{6}$ VENOSA, Silvio de Salvo. Direito Civil: Responsabilidade Civil. 15. ed. São Paulo: Atlas, 2015.

7 MÉDICI, Sergio de Oliveira, Contravenções Penais. Bauru/SP: Javoli, 1988, p. 214.

8 VENOSA, Silvio de Salvo. Direito Civil: Responsabilidade Civil. 15. ed. São Paulo: Atlas, 2015, p. 288.
} 
SILVA, Leonardo dos Santos; SIMINI, Danilo Garnica. Liberdade de culto e seus eventuais excessos: o exemplo da cidade de Ituverava/SP. Revista Eletrônica Direito e Política, Programa de PósGraduação Stricto Sensu em Ciência Jurídica da UNIVALI, Itajaí, v.12, n.3, $3^{\circ}$ quadrimestre de 2017. Disponível em: www.univali.br/direitoepolitica - ISSN 1980-7791

Tais ações podem ser cumuladas com danos morais e materiais ou ação de reparação/indenização. Deve-se ressaltar ser desnecessária a perícia para se comprovar o dano, podendo este ser comprovado por documentos, testemunhas, indícios e outros meios de prova. Desta forma, verifica-se que a violação do direito ao sossego poderá ocasionar consequências penais, cíveis e ambientais, podendo o prejudicado acionar o Poder Judiciário a fim de que este tome as providências necessárias em termos de responsabilização dos autores do dano, fazendo com que o direito em questão seja efetivamente protegido de outras violações. Feitas tais considerações, nos próximos tópicos iremos discutir com um pouco mais de profundidade a responsabilidade civil das instituições religiosas.

\section{RESPONSABILIDADE CIVIL DAS INSTITUIÇõES RELIGIOSAS}

A responsabilidade civil pode ser classificada em responsabilidade contratual ou extracontratual, bem como poderá igualmente ser classificada em responsabilidade objetiva ou subjetiva e, finalmente, poderá ser classificada em responsabilidade direta ou indireta. Estas são as classificações mais usuais apresentadas pela literatura de Direito Civil, particularmente, pelos autores que trabalham a temática da responsabilidade civil.

A responsabilidade contratual ocorre quando se tem um contrato e deste resultando-se um ilícito contratual, seja pela inadimplência ou pelo não cumprimento da obrigação, gerando o dever de indenizar. Maria Helena Diniz discorre que "quando ocorre inadimplemento do contrato, não é a obrigação contratual que movimenta a responsabilidade, uma vez que surge uma nova obrigação que se substitui à preexistência no todo ou em parte" ${ }^{\prime \prime}$. Assim sendo, a responsabilidade contratual é o resultado existente quando da violação de uma obrigação, assim sendo, compete ao devedor o dever de provar o inadimplemento, a culpa inexistente ou qualquer outro tipo de excludente. Tal preceito está fundamentado no artigo 389 do Código Civil que enuncia "não cumprida a obrigação, responde o devedor por perdas e danos, mais juros e atualização

\footnotetext{
${ }^{9}$ DINIZ, Maria Helena. Curso de Direito Civil: 7. Responsabilidade Civil. 26. ed. São Paulo: Saraiva, 2012. p. 146.
} 
SILVA, Leonardo dos Santos; SIMINI, Danilo Garnica. Liberdade de culto e seus eventuais excessos: o exemplo da cidade de Ituverava/SP. Revista Eletrônica Direito e Política, Programa de PósGraduação Stricto Sensu em Ciência Jurídica da UNIVALI, Itajaí, v.12, n.3, $3^{\circ}$ quadrimestre de 2017. Disponível em: www.univali.br/direitoepolitica - ISSN 1980-7791

monetária segundo índices oficiais regularmente estabelecidos, e honorários de advogado".

De outra parte, a responsabilidade extracontratual resulta do inadimplemento por pessoa capaz ou incapaz, não havendo vínculo entre as partes, não estando as partes ligadas por uma relação obrigacional ou contratual, sendo que tal responsabilidade também acarretará ao responsável o dever de reparar o dano. Tanto em uma quanto em outra ocorre a violação de um dever jurídico preexistente. De qualquer forma, temos a violação de um dever jurídico, tanto na responsabilidade contratual quanto na extracontratual. Essa responsabilidade também chamada de Aquiliana, devido ao advento de Lex Aquilia, que para alguns doutrinadores, a culpa caracteriza o delito, com isso havendo a reparação do dano material quanto moral.

Os dispositivos legais da responsabilidade extracontratual encontram-se nos artigos 186 e 927 do Código Civil de 2002.

Art. 186. Aquele que, por ação ou omissão voluntária, negligência ou imprudência, violar direito e causar dano a outrem, ainda que exclusivamente moral, comete ato ilícito.

Art. 927. Aquele que, por ato ilícito (arts. 186 e 187), causar dano a outrem, fica obrigado a repará-lo.

Portanto, a obrigação de indenizar a vítima cabe em ambas responsabilidades, sendo diferenciado apenas o ônus da prova. Na extracontratual cabe à vítima demonstrar a culpa do agente e o dano causado pela vítima. Na responsabilidade contratual, tem que ser provado que não houve descumprimento das cláusulas contratuais ${ }^{10}$.

A responsabilidade subjetiva se caracteriza quando presentes os elementos subjetivos da culpa e do dolo. Havendo uma violação em razão de culpa ou dolo será realizada a reparação de danos. Na responsabilidade objetiva, por sua vez,

\footnotetext{
${ }^{10}$ DINIZ, Maria Helena. Curso de Direito Civil: 7. Responsabilidade Civil. 26. ed. São Paulo: Saraiva, 2012
} 
SILVA, Leonardo dos Santos; SIMINI, Danilo Garnica. Liberdade de culto e seus eventuais excessos: o exemplo da cidade de Ituverava/SP. Revista Eletrônica Direito e Política, Programa de PósGraduação Stricto Sensu em Ciência Jurídica da UNIVALI, Itajaí, v.12, n.3, $3^{\circ}$ quadrimestre de 2017. Disponível em: www.univali.br/direitoepolitica - ISSN 1980-7791

será irrelevante se a conduta foi culposa ou dolosa, bastando haver nexo causal entre o dano e o prejuízo sofrido para que surja o dever de indenizar ${ }^{11}$.

Por fim, na responsabilidade direta o dano é causado diretamente pelo agente e este responde pelos seus atos, ao contrário da chamada responsabilidade indireta, quando o ato de terceiro é vinculado ao agente que deverá indenizar, como por exemplo, um dano causado por animal que estiver sob a guarda de alguém. Nesse caso o dano foi provocado pelo animal, mas o ser humano é quem deverá ser responsabilizado ${ }^{12}$.

Quando ocorrer dúvidas sobre qual tipo de responsabilidade está presente em um determinado dano, cabe ver se o ato ilícito é decorrente ou não de um contrato. Assim para configurar a responsabilidade contratual será necessário que o devedor não cumpra com suas obrigações, que tenha agido com dolo ou culpa e que haja o nexo causal em certas atitudes do devedor. Ademais, quando não houver contrato e ocorrer o ato ilícito, causando prejuízo estará configurada a responsabilidade extracontratual. ${ }^{13}$

No que diz respeito aos pressupostos da responsabilidade civil, o artigo 186 do Código Civil enuncia que aquele que por ação ou omissão voluntária, negligência ou imprudência violar direito e causar dano a outrem, ainda que exclusivamente moral, comete ato ilícito. Ademais, o artigo 187 do Código Civil enuncia que também comete ato ilícito o titular de um direito que, ao exercê-lo, excede manifestamente os limites impostos pelo seu fim econômico ou social, pela boa-fé ou pelos bons costumes.

Nesse contexto, nos termos do artigo 927 também do Código Civil, aquele que, por ato ilícito, causar dano a outrem, fica obrigado a repará-lo. Feitas tais

\footnotetext{
${ }^{11}$ DINIZ, Maria Helena. Curso de Direito Civil: 7. Responsabilidade Civil. 26. ed. São Paulo: Saraiva, 2012

12 VENOSA, Silvio de Salvo. Direito Civil: Responsabilidade Civil. 15. ed. São Paulo: Atlas, 2015.

13 VENOSA, Silvio de Salvo. Direito Civil: Responsabilidade Civil. 15. ed. São Paulo: Atlas, 2015.
} 
SILVA, Leonardo dos Santos; SIMINI, Danilo Garnica. Liberdade de culto e seus eventuais excessos: o exemplo da cidade de Ituverava/SP. Revista Eletrônica Direito e Política, Programa de PósGraduação Stricto Sensu em Ciência Jurídica da UNIVALI, Itajaí, v.12, n.3, $3^{\circ}$ quadrimestre de 2017. Disponível em: www.univali.br/direitoepolitica - ISSN 1980-7791

considerações, podemos agora examinar esses pressupostos da responsabilidade civil, quais sejam, ação, dano e nexo de causalidade.

A ação pode ser comissiva ou omissiva, sendo qualificada juridicamente como ato lícito ou ilícito. Tem se ato ilícito quando uma ação contraria o dever geral previsto no ordenamento jurídico, baseando-se na ideia de culpa. Não havendo culpa, a responsabilidade se fundamente no risco, que se impõe na atualidade com a insuficiência da culpa e assim surge como uma alternativa para que os danos sejam resolvidos. A ação comissiva é uma ação voluntária que acaba causando um prejuízo. Sendo diferente da omissão, quando se tem um não fazer, a pessoa deixa de agir quando poderia, e com isso acaba permitindo que alguém venha a sofrer um dano ${ }^{14}$

Nesse contexto, quando ocorre o dano causado à vítima por atos omissivos ou comissivos do agente, este responde pelo dano causado, não podendo haver responsabilidade civil sem dano, sendo obrigatório a prova real da lesão. Um dos objetivos da responsabilidade civil é a reparação do dano sofrido, mas sem o dano, não se tem reparação. O dano pode ser material ou imaterial. Constitui dano material quando o dano é diretamente à vítima ou em seu patrimônio. $O$ dano material sempre será o dano causado ao bem jurídico de valor econômico, tanto quando ocorrer uma agressão à vítima ou quando se causa um dano patrimonial, sendo esse dano reparado em forma de pecúnia. O dano imaterial é quando se sofre dano à imagem, à honra e à liberdade da pessoa, não estando ligado ao patrimônio, conforme disposto no artigo $5^{\circ}$, incisos $\mathrm{V}$ e $\mathrm{X}$, da Constituição Federal ${ }^{15}$.

Art. $5^{0}$ Todos são iguais perante a lei, sem distinção de qualquer natureza, garantindo-se aos brasileiros e aos estrangeiros residentes no País a inviolabilidade do direito à vida, à liberdade, à igualdade, à segurança e à propriedade, nos termos seguintes:

14 GAGliano, Pablo Stolze; P. FILHO, Rodolfo. Novo curso de Direito Civil: Direito de Familia. 6. ed. São Paulo: Saraiva, 2011.

15 GAGLIANO, Pablo Stolze; P. FILHO, Rodolfo. Novo curso de Direito Civil: Direito de Familia. 6. ed. São Paulo: Saraiva, 2011. 
SILVA, Leonardo dos Santos; SIMINI, Danilo Garnica. Liberdade de culto e seus eventuais excessos: o exemplo da cidade de Ituverava/SP. Revista Eletrônica Direito e Política, Programa de PósGraduação Stricto Sensu em Ciência Jurídica da UNIVALI, Itajaí, v.12, n.3, $3^{\circ}$ quadrimestre de 2017. Disponível em: www.univali.br/direitoepolitica - ISSN 1980-7791

$V$ - é assegurado o direito de resposta, proporcional ao agravo, além da indenização por dano material, moral ou à imagem;

X - são invioláveis a intimidade, a vida privada, a honra e a imagem das pessoas, assegurado o direito a indenização pelo dano material ou moral decorrente de sua violação;

Na lição de Pablo Stolze Gagliano "trata-se de um dano ou lesão cujo conteúdo não é pecuniário, pois não está relacionada ao patrimônio da vítima, mas sim à sua imagem e reputação, como ela é vista na sociedade e o que as pessoas pensam sobre ela"16. O dano é quando ocorre a lesão de um bem ou um direito, tendo perda significativa de um patrimônio material e até mesmo moral, resultante de uma ação de conduta de um certo agente, fazendo com que o lesado tenha direito de ser ressarcido e até mesmo compensando o dano quando não tiver como ser reparado.

Na lição de Sílvio de Salvo Venosa:

Somente haverá possibilidade de indenização se o ato ilícito ocasionar dano. Cuida-se, portanto, do dano injusto. Em concepção mais moderna, pode-se entender que a expressão dano injusto traduz a mesma noção de lesão a um interesse, expressão que se torna mais própria modernamente, tendo em vista ao vulto que tomou a responsabilidade civil. [...] Trata-se, em última análise, de interesse que são atingidos injustamente. O dano ou interesse deve ser atual e certo; não sendo indenizáveis, a principio, danos hipotéticos. Sem dano ou sem interesse violado, patrimonial ou moral, não se corporifica a indenização. A materialização do dano acorre com a definição do efetivo prejuízo suportado pela vítima. ${ }^{17}$

Por fim, há o nexo de causalidade, sendo um dos pressupostos para configurar a responsabilidade civil e também o dever de indenizar. Nas lições de Silvio Venosa ${ }^{18}(2003$, p 39) o nexo de causalidade "é o liame que une a conduta

16 GAgliano, Pablo Stolze; P. FILHO, Rodolfo. Novo curso de Direito Civil: Direito de Familia. 6. ed. São Paulo: Saraiva, 2011, p. 86.

17 VENOSA, Silvio de Salvo. Direito Civil: Responsabilidade Civil. p. 28.

18 VENOSA, Silvio de Salvo. Direito Civil: Responsabilidade Civil. p. 39 
SILVA, Leonardo dos Santos; SIMINI, Danilo Garnica. Liberdade de culto e seus eventuais excessos: o exemplo da cidade de Ituverava/SP. Revista Eletrônica Direito e Política, Programa de PósGraduação Stricto Sensu em Ciência Jurídica da UNIVALI, Itajaí, v.12, n.3, $3^{\circ}$ quadrimestre de 2017. Disponível em: www.univali.br/direitoepolitica - ISSN 1980-7791

do agente ao dano. É por meio do exame da relação causal que concluímos quem foi o causador do dano. Trata-se de um elemento indispensável".

O presente trabalho tem como objetivo discutir eventuais excessos decorrentes da liberdade de culto, especialmente, no que diz respeito à perturbação do sossego provocado pelo som produzido pelas igrejas em seus cultos. Nesse contexto, se mostra útil ao trabalho investigar se o Judiciário vem analisando tal questão e, em caso positivo, de que forma o problema é tratado pela jurisprudência.

Assim, foi feita pesquisa de jurisprudência nos sites do Superior Tribunal de Justiça e do Tribunal de Justiça de São Paulo. O Tribunal de Justiça de São Paulo foi um dos escolhidos para a pesquisa tendo em vista tratar-se do maior Tribunal da América Latina, o que em princípio facilitaria a investigação em razão de uma possível grande quantidade de casos. O Superior Tribunal de Justiça foi também escolhido por ser a instância acima do Tribunal de Justiça de São Paulo, sendo que a prática forense demonstra que muitos processos julgados pelo Tribunal de Justiça de São Paulo chegam até o Superior Tribunal de Justiça em Brasília através da interposição de recursos especiais.

Foram encontrados alguns jugados no que diz respeito à responsabilidade civil das instituições religiosas. No mecanismo de pesquisa foram utilizados os seguintes termos como palavras chaves: "igreja", "som", "indenização", tendo como resultado 6 (seis) julgados no Tribunal de Justiça de São Paulo e 2 (dois) julgados no Superior Tribunal de Justiça, sendo que todos são referentes ao ano de 2016.

O primeiro acordão do Tribunal de Justiça de São Paulo é referente ao processo $\mathrm{n}^{\circ}$ 0000080-49.2011.8.26.0431, onde a apelante é a Igreja Universal do Reino de Deus e os apelados Martha Haddad e Antônio Luiz, voto $n^{\circ} 27.984$, julgado pelos Desembargadores Jonas Varejão, Nestor Duarte e Cristina Zucchi. ${ }^{19}$ 3 ? conversation Id $=$ \&paginaConsulta $=1$ \&localPesquisa. cdLocal $=5 \& \mathrm{cb} P$ Pesquisa $=$ NUMPROC\&tipoNuPro cesso $=$ UNIFICADO\&numeroDigitoAnoUnificado $=0000080$ -

49.2011\&foroNumeroUnificado $=0431 \&$ dePesquisaNuUnificado $=0000080-$

49.2011.8.26.0431\&dePesquisa $=$ \&uuidCaptcha $=$ 
SILVA, Leonardo dos Santos; SIMINI, Danilo Garnica. Liberdade de culto e seus eventuais excessos: o exemplo da cidade de Ituverava/SP. Revista Eletrônica Direito e Política, Programa de PósGraduação Stricto Sensu em Ciência Jurídica da UNIVALI, Itajaí, v.12, n.3, $3^{\circ}$ quadrimestre de 2017. Disponível em: www.univali.br/direitoepolitica - ISSN 1980-7791

A ré Igreja Universal entrou com recurso para que fosse reformada a decisão em que foi condenada a pagar indenização no valor de $\mathrm{R} \$ 7,240.00$ (sete mil duzentos e vinte e quatro reais), correspondentes à dez salários mínimos. Foi determinado que a ré cessasse de imediato qualquer atividade sonora, pois a instituição não preenchia as exigências das normas da ABNT, constatação feita por laudo técnico pericial elaborado pelo município.

Através desse laudo e por meio de testemunhas foi constatado que a ré ultrapassava os limites de $40 \mathrm{Db}$. Assim, os autores da demanda fundamentaram seu processo com base no artigo 1.277 do Código Civil que trata do uso anormal da propriedade. Os Desembargadores negaram provimento ao recurso, em conformidade com o voto do Relator, sendo que o julgamento foi realizado em 02 de setembro de 2016 .

Posteriormente, em 30/09/2016, temos o Voto n 16225 , proferido no Agravo de instrumento $\mathrm{n}^{\circ}$ 2155206-17.2016.8.26.0000, onde a agravante é a Igreja Evangélica Assembleia de Deus da cidade de Presidente Bernardes e o agravado Reginaldo Aparecido Crisostomo. ${ }^{20}$

Neste agravo se discutiu a obrigação de fazer cumulada com indenização, em fase de cumprimento de sentença, onde foi determinado que o estabelecimento fosse lacrado e que fosse feita penhora de bens. Esses bens eram duas caixas de som, uma guitarra e um violão. Essa ação foi julgada procedente para que a requerida cessasse a produção de som e ruídos superiores a 45 Db no período noturno e de $50 \mathrm{Db}$ no período diurno, com multa de $\mathrm{R} \$ 1,000.00$ (mil reais) pelo descumprimento. A ré foi condenada a efetuar obras para a contenção do som, já que de acordo com os julgadores a liberdade de culto não autoriza que se ignore a perturbação ao sossego.

Em relação ao Superior Tribunal de Justiça, temos o Recurso Especial 2007/0101431-8, que teve como relatora a Ministra Nancy Andrighi, vinculada à

20 Disponível em https://esaj.tjsp.jus.br/cposg/search.do?conversationId=\&paginaConsulta $=1 \&$ localPesquisa. cdLocal =5\&cbPesquisa =NUMPROC\&tipoNuProcesso=UNIFICADO\&numeroDigitoAnoUn ificado $=2155206-17.2016 \&$ foroNumeroUnificado $=0000 \&$ dePesquisaNuUnificado $=2155206$ -

17.2016.8.26.0000\&de Pesquisa=\&uuidCaptcha. Acesso em ago de 2017. 
SILVA, Leonardo dos Santos; SIMINI, Danilo Garnica. Liberdade de culto e seus eventuais excessos: o exemplo da cidade de Ituverava/SP. Revista Eletrônica Direito e Política, Programa de PósGraduação Stricto Sensu em Ciência Jurídica da UNIVALI, Itajaí, v.12, n.3, $3^{\circ}$ quadrimestre de 2017. Disponível em: www.univali.br/direitoepolitica - ISSN 1980-7791

Terceira Turma. De acordo com a ementa, o recorrido, Arthur Roberto de Abreu Oliveira ajuizou ação cominatória de obrigação de fazer, cumulada com pedido de compensação por danos morais, com alegação de perturbação de sossego, em face da Paróquia São João Batista de Dourado. Consta do acórdão que a Paróquia instalou um sistema de som na torre da igreja e que no decorrer do dia transmitia mensagens religiosas aos fiéis. A população disse que inexistia qualquer incômodo causado pela transmissão, mas o recorrido que tem sua residência nas proximidades da paróquia pleiteou compensação por danos morais, pois muito te incomodava tal atitude da Paróquia.

O Superior Tribunal de Justiça deu provimento ao Recurso Especial, reconhecendo a inexistência de dano moral. O acórdão ressaltou que os ruídos emitidos pela Paróquia faziam parte da tradição da cidade e com isso não causariam dano moral. Ademais, o Superior Tribunal de Justiça determinou que os ruídos obedecessem aos limites previstos na legislação correspondente, sendo fixado o valor de $\mathrm{R} \$ 30.000,00$ (trinta mil reais) a título de multa no caso de descumprimento.

Os precedentes indicados acima demonstram que a liberdade de culto não é absoluta e as instituições religiosas devem se adequar em relação aos ruídos produzidos, já que devem respeitar a coletividade como um todo, especialmente, aqueles que não partilham das mesmas crenças e, portanto, não frequentam tais religiões. Ademais, também ficou demonstrado que as igrejas poderão ser responsabilizadas pelo excesso de barulho, inclusive, sendo condenadas ao pagamento de indenizações. Feitas considerações, no próximo tópico iremos discutir a problemática dos excessos da liberdade de culto na cidade de Ituverava.

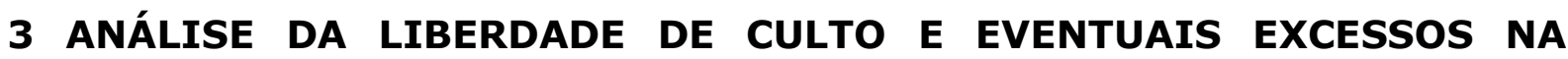 REALIDADE DE ITUVERAVA}

Na cidade de Ituverava/SP, no dia 2 de outubro de 2006, entrou em vigor a Lei Complementar $n^{\circ} .4 .161 \backslash 13$, que em seu artigo $1^{\circ}$, institui o Código de Posturas no Município de Ituverava e dá outras providências, para a promoção do bemestar e da qualidade de vida no ambiente municipal. 
SILVA, Leonardo dos Santos; SIMINI, Danilo Garnica. Liberdade de culto e seus eventuais excessos: o exemplo da cidade de Ituverava/SP. Revista Eletrônica Direito e Política, Programa de PósGraduação Stricto Sensu em Ciência Jurídica da UNIVALI, Itajaí, v.12, n.3, $3^{\circ}$ quadrimestre de 2017. Disponível em: www.univali.br/direitoepolitica - ISSN 1980-7791

O Título IV trata da segurança e ordem pública. O Capítulo I trata do sossego, enunciando o artigo 78 ser "dever do Poder Executivo zelar pela manutenção do sossego, da segurança e da ordem em todo o território do Município, nos limites de sua competência constitucional". De outra parte, o artigo 79, da mesma Lei Complementar, dispõe que o Poder Executivo usará de meios eletrônicos para acompanhar, avaliar e atuar na segurança e na ordem em vias e logradouros públicos.

O artigo 80 veda aos estabelecimentos de qualquer natureza, edificações, casa de diversões ou nas vias públicas, a produção de sons ou ruídos que ultrapassem os limites orientados nas normas 7.731 e 10.151 da ABNT, devendo os estabelecimentos que produzam ruídos superiores a tais limites se adequar acusticamente, impedindo a propagação do som.

No dia 05 de julho de 2013 a Câmara Municipal de Ituverava aprovou a Lei nº. 4.161/13. Essa lei dispõe sobre ruídos urbanos e proteção ao bem-estar e do sossego público, regulamentando e dispondo sobre os artigos 78,79,80 e 81 da Lei 003/2006. 0 artigo $^{\circ}$ da referida Lei enuncia ser "proibido perturbar o sossego e o bem-estar públicos com qualquer tipo de som, ruído ou vibração", sendo que as vibrações serão consideradas prejudiciais quando ocasionarem qualquer tipo de dano ao bem estar público (art. $1^{\circ}, \S^{\circ}$ ).

$\mathrm{O}$ artigo $2^{\circ}$ explica que os níveis de intensidades de ruídos serão fixados por lei e que o nível equivalente e os métodos para medição, obedecerão às recomendações das normas 10.151 e 10.152 da ABNT, já vistas anteriormente.

O artigo $3^{\circ}$, por sua vez, estabelece os critérios e também os padrões que devem ser obedecidos, decorrente de qualquer tipo de ruído. Em seu $\S 1^{\circ}$ o referido artigo expõe que as medições devem ser feitas a 5 metros de qualquer divisa do imóvel, ou medido dentro dos limites reais da propriedade que está causando o suposto incômodo. O $\S 2^{\circ}$ determina que "nenhuma fonte de emissão sonora de logradouros públicos não excederá o nível sonoro de $80 \mathrm{db}$ ", e $\S 3^{\circ}$ enuncia que os ruídos provocados por carros de som, motos e similares usados em propaganda, não poderão exceder o limite de $65 \mathrm{db}$. No entanto, há de se verificar que no $\S 2^{\circ}$ da referida lei, foram encontradas divergências em relação aos níveis de decibéis, 
SILVA, Leonardo dos Santos; SIMINI, Danilo Garnica. Liberdade de culto e seus eventuais excessos: o exemplo da cidade de Ituverava/SP. Revista Eletrônica Direito e Política, Programa de PósGraduação Stricto Sensu em Ciência Jurídica da UNIVALI, Itajaí, v.12, n.3, $3^{\circ}$ quadrimestre de 2017. Disponível em: www.univali.br/direitoepolitica - ISSN 1980-7791

se comparados com os níveis estabelecidos na norma 10.152 da ABNT, pois esta estipula os níveis tolerados em cada situação e estabelecimentos, variando de 30 até $60 \mathrm{db}$.

Em hospitais e suas dependências os níveis variam de 35 à 55db, nas escolas e suas dependências vão de 35 à 55 db, o mesmo estipulado para hotéis e suas dependências. Em residências o níveis variam de 35 à $50 \mathrm{db}$, em auditórios e suas dependências como teatros, cinemas e etc, variam entre 30 à $45 \mathrm{db}$, de restaurante 40 à 50db, já em escritórios como em salas de reuniões variam de 30 à 40 e em salas de mecanografia de 50 à $60 \mathrm{db}$, como também em locais para esportes de 45 à a $60 \mathrm{db}$. Por fim, nas igrejas e templos seus níveis variam de 40 à 50 bd (tabela de níveis em anexo)

O artigo $4^{\circ}$ da Lei Municipal $n^{\circ} 4.161 / 13$ trata das penalidades para quem infringir tal lei, acarretando em notificação por escrito, multa simples ou diária, embargo do trabalho, cassação imediata do alvará, perda ou restrição de incentivos e benefícios fiscais concedidos pelo município. No $\S 1^{\circ}$ do mesmo dispositivo temos que se o infrator assinar um termo de compromisso com as autoridades ambiental, Polícia Miliar ou a Civil, para que assim cesse ou corrija a poluição sonora, e se forem cumpridas todas obrigações assumidas pelo infrator, no prazo de 30 dias, poderá a multa ter uma redução de até $90 \%$ do valor.

Ademais, o $\S 2^{\circ}$ classifica as infrações como leves, graves e gravíssimas. Leves quando o infrator seja beneficiado por fatores atenuantes, como menor grau de compreensão, quando ocorrer 0 arrependimento eficaz e o infrator espontaneamente se manifeste para a reparação do dano, e ser um infrator primário. As graves serão quando o infrator for reincidente ou agir com dolo direto ou eventual. Por fim, a gravíssima quando for verificada a existência de três ou mais circunstâncias e reincidência.

O artigo $5^{\circ}$ da Lei Municipal 4.161/13 enuncia que a Secretária do Meio Ambiente, a Policia Militar e Civil juntamente com o município, exercerão o poder de fiscalização das fontes poluidoras, estabelecendo programas de educação e conscientização a respeito. Analisando o artigo $5^{\circ}$ podemos notar que tal preceito não esta sendo cumprido, muito menos havendo programas de educação e 
SILVA, Leonardo dos Santos; SIMINI, Danilo Garnica. Liberdade de culto e seus eventuais excessos: o exemplo da cidade de Ituverava/SP. Revista Eletrônica Direito e Política, Programa de PósGraduação Stricto Sensu em Ciência Jurídica da UNIVALI, Itajaí, v.12, n.3, $3^{\circ}$ quadrimestre de 2017. Disponível em: www.univali.br/direitoepolitica - ISSN 1980-7791

conscientização, visto que os excessos de ruídos provocados pelas instituições religiosas constituem o motivo para ser feito o presente trabalho.

Ademais, foram feitas pesquisas de processos juntos a Prefeitura e ao Fórum local, mas não foram encontrados processos envolvendo especificamente instituições religiosas e excesso de barulho. Inicialmente, na Prefeitura foi perguntado ao Secretário do Meio Ambiente, Edson Barbosa Domiciano, se havia processos de perturbação de sossego envolvendo igrejas, onde foi informado que quando tinha alguma ocorrência o procedimento da Prefeitura era ouvir as partes e tentar uma conciliação.

Em seguida, em pesquisa de processos no Fórum local foram encontrados processos sobre perturbação de sossego com fundamento no artigo 42 da Lei de Contravenções Penais. Foram analisados três processos, onde, um era por perturbação entre vizinhos de área de lazer, em que houve uma festa com brigas na madrugada, outro de vizinho de república estudantil, onde a reclamação foi o som alto em um dia de festa, e outro entre comerciantes onde um colocava mesas e cadeiras em frente ao comércio vizinho.

Nos três processos o Ministério Público pediu o arquivamento, tendo em vista que os elementos de prova neles eram insuficientes a ensejar o ajuizamento de ação penal, com o fundamento de que, para a consumação da contravenção penal, não basta que uma pessoa ou um grupo reduzido de pessoas se sinta atingido pela perturbação, tendo que haver um grupo considerável de indivíduos incomodados, pois a Lei de Contravenções Penais utiliza a palavra "alheios", no plural.

Após a análise doutrinária, procurou-se fundamentar o estudo com base na visão dos vizinhos que se sentiram ou não incomodados com os cultos. Foi formulado um questionário (anexo) com treze perguntas que foram feitas para dez moradores vizinhos de igrejas, sendo parede com parede ou residentes defronte às instituições religiosas, todos da cidade de Ituverava.

A escolha dessas pessoas para a pesquisa se deu por conta de que os ruídos emitidos por tais instituições afetam principalmente os moradores ao lado e de frente das igrejas. Essas pessoas foram selecionadas por chamada em rede social, 
SILVA, Leonardo dos Santos; SIMINI, Danilo Garnica. Liberdade de culto e seus eventuais excessos: o exemplo da cidade de Ituverava/SP. Revista Eletrônica Direito e Política, Programa de PósGraduação Stricto Sensu em Ciência Jurídica da UNIVALI, Itajaí, v.12, n.3, $3^{\circ}$ quadrimestre de 2017. Disponível em: www.univali.br/direitoepolitica - ISSN 1980-7791

conforme consta em anexo, sendo suas respostas enviadas pelo mesmo aplicativo, mas no modo privado. Não serão discriminados os nomes das pessoas que responderam o questionário, sendo que tal pesquisa é de inteira responsabilidade do autor. Abaixo seguem as respostas ao questionário proferidas pelos moradores da Comarca de Ituverava.

Questão 1 (um), sobre ter religião, oito pessoas responderam que SIM e duas pessoas responderam que NÃO tem religião.

Questão 2 (dois), sobre seguir a mesma religião que a igreja vizinha, duas pessoas disseram que SIM, ou seja, seguem a religião da igreja vizinha e oito responderam que NÃO.

Questão 3 (três), todos responderam que NÂO frequentam a igreja vizinha.

Questão 4 (quatro), duas pessoas responderam que NÃO ouvem as atividades da igreja vizinha, sendo que oito pessoas responderam que SIM.

Questão 5 (cinco), três pessoas deram a nota 10 para o volume exercido dentro da igreja, três pessoas deram a nota 8,2 pessoas deram a nota 9 e duas pessoas deram a nota 1 , que acham baixo o som produzido pela igreja vizinha. Nesta questão já podemos notar que a maioria das igrejas emite ruídos acima do considerado razoável pelas pessoas entrevistadas para este trabalho.

Questão 6 (seis), três pessoas responderam que as atividades exercidas pelas igrejas como cultos e louvores NÃO os incomodam no convívio dentro de sua casa, mas novamente oito pessoas responderam que SIM, ou seja, que os cultos e louvores os incomodam.

Questão 7 (sete), oito pessoas disseram que SIM, que acreditam que o volume de som na pregação ou em músicas vão além do permitido em leis, e apenas 2 pessoas acham que NÃO.

Questão 8 (oito), cinco pessoas deram a nota 10, duas deram a nota 8 e 1 pessoa a nota 9, que corresponde a serem muito incomodados pelas igrejas vizinhas e duas pessoas deram a nota 1 , que não são perturbados pelas igrejas. 
SILVA, Leonardo dos Santos; SIMINI, Danilo Garnica. Liberdade de culto e seus eventuais excessos: o exemplo da cidade de Ituverava/SP. Revista Eletrônica Direito e Política, Programa de PósGraduação Stricto Sensu em Ciência Jurídica da UNIVALI, Itajaí, v.12, n.3, $3^{\circ}$ quadrimestre de 2017. Disponível em: www.univali.br/direitoepolitica - ISSN 1980-7791

Questão 9 (nove), essa questão é sobre se algum dos entrevistados já fez algum tipo de reclamação sobre a perturbação junto às igrejas vizinhas, sendo que cinco pessoas responderam que SIM e cinco NÃO.

Questão 10 (dez), em continuidade com a questão anterior foi perguntado se surtiu algum efeito tais reclamações, cinco pessoas responderam N/A que não se aplicava a resposta e cinco responderam que NÃO foram solucionados os problemas,

Questão 11 (onze), foi perguntado nessa questão se algum dos entrevistados já fez reclamações junto à Policia ou à Prefeitura da cidade, e apenas uma pessoa respondeu que SIM e nove NÃO, ou seja, não fizeram nenhuma reclamação ou boletim de ocorrência.

Questão 12 (doze), perguntado se o problema foi solucionado, 5 pessoas disseram que NÃO e cinco responderam N/A, que não se aplicava a resposta.

Questão 13 (treze), foi perguntado se eles achavam que a igreja deveria ter um sistema de acústica, sendo unânime todos responderam que SIM.

Diante tal questionário, notamos que muitas vezes as igrejas de Ituverava produzem ruídos em excesso, que incomodam os seus vizinhos. Porém, ao mesmo tempo, constatamos através do questionário que nem todos os vizinhos tomam providências para que o seu direito ao sossego seja respeitado.

\section{CONSIDERAÇÕES FINAIS}

O presente trabalho teve como objetivo discutir os excessos decorrentes da liberdade de culto à luz do Direito, especialmente, os excessos relacionados aos ruídos produzidos pelas igrejas em desconformidade com a legislação pertinente, pois tais excessos podem em tese violar o direito ao sossego dos indivíduos. Inicialmente, foi feita uma discussão constitucional acerca da liberdade de culto e o direito ao sossego enquanto direito fundamental.

O trabalho também realizou uma discussão referente à responsabilidade civil das instituições religiosas, apresentando primeiramente conceitos mais gerais, tais como os relacionados às espécies de responsabilidade e os seus pressupostos. 
SILVA, Leonardo dos Santos; SIMINI, Danilo Garnica. Liberdade de culto e seus eventuais excessos: o exemplo da cidade de Ituverava/SP. Revista Eletrônica Direito e Política, Programa de PósGraduação Stricto Sensu em Ciência Jurídica da UNIVALI, Itajaí, v.12, n.3, $3^{\circ}$ quadrimestre de 2017. Disponível em: www.univali.br/direitoepolitica - ISSN 1980-7791

Nesta parte também foram apresentados alguns precedentes extraídos do Superior Tribunal de Justiça e do Tribunal de Justiça de São Paulo a fim de se demonstrar de que forma a jurisprudência vem tratando a responsabilidade civil das instituições religiosas em casos de excessos de ruídos produzidos durante suas celebrações. A análise da jurisprudência demonstrou que a liberdade de culto não é absoluta e que as organizações religiosas devem respeitar a legislação que estabelece os limites de ruídos. Em outras palavras, a jurisprudência apresentada indicou que deve haver uma harmonia entre a liberdade de culto e o direito ao sossego.

Por fim, no terceiro tópico foi realizado um estudo envolvendo a cidade de Ituverava. O município de Ituverava possui legislação que trata do sossego e do bem-estar públicos, apresentando limites de ruídos que devem ser respeitados pelos mais diversos estabelecimentos, inclusive, igrejas de todas as religiões. No mesmo tópico também ficou demonstrado que não existem processos na Prefeitura ou no Fórum que tratem especificamente de perturbação de sossego em razão da atividade das igrejas na cidade, fato que pode ser explicado pelas respostas obtidas nos questionários aplicados, já que boa parte dos entrevistados, mesmo reconhecendo que as igrejas perturbam o sossego, não tomaram providências efetivas para que os seus direitos fossem efetivamente respeitados.

Portanto, acredita-se que o presente trabalho possa contribuir com os debates sobre o tema, mesmo sem ter a intenção de esgotar o assunto. De qualquer forma, o trabalho evidenciou a importância da liberdade de culto e o direito ao sossego, bem como ressaltou que ambos não são absolutos, exigindo-se dos envolvidos uma conduta harmoniosa. Ademais, espera-se que o trabalho possa contribuir para demonstrar um velho problema da sociedade brasileira, qual seja, a omissão da sociedade mesmo quando se mostra necessária a luta por uma maior proteção de seus próprios direitos. 
SILVA, Leonardo dos Santos; SIMINI, Danilo Garnica. Liberdade de culto e seus eventuais excessos: o exemplo da cidade de Ituverava/SP. Revista Eletrônica Direito e Política, Programa de PósGraduação Stricto Sensu em Ciência Jurídica da UNIVALI, Itajaí, v.12, n.3, $3^{\circ}$ quadrimestre de 2017. Disponível em: www.univali.br/direitoepolitica - ISSN 1980-7791

\section{REFERÊNCIA DAS FONTES CITADAS}

BRASIL. Superior Tribunal de Justiça. Recurso Especial no 951868 / SP. Recorrente: PARÓQUIA SÃO JOÃO BATISTA DE DOURADO. Recorrido: ARTHUR ROBERTO DE ABREU OLIVEIRA. Relator: Ministra NANCY ANDRIGHI. Brasília, DF, 13 de novembro de 2008. Disponível em: <http://www.stj.jus.br/SCON/jurisprudencia/toc.jsp?livre=igreja+som+indenizac ao\&\&tipo;_visualizacao=RESUMO\&b=ACOR>. Acesso em: 11 out. 2016.

BRASIL. Tribunal de Justiça. Apelação no 0000268-60.2011.8.26.0037. Fabiana Angelica do Nascimento. Marilene Sanches da Silva. Relator: Desembargador Morais Pucci. Araraquara, SP, 15 de agosto de 2016. Tjsp. São Paulo, 15 ago. 2016.

Disponível

em: <https://esaj.tjsp.jus.br/cjsg/getArquivo.do;jsessionid=839DF045AA3F47AA109 78D6967052E40.cjsg3 cdAcordao $=9697144 \&$ cdForo $=0 \& v$ ICaptcha $=$ CTPJU $>$. Acesso em: 20 out. 2016.

BRASIL. Tribunal de Justiça. Agravo de Instrumento no 21552061720168260000. Igreja Evangélica Assembleia de Deus - Presidente Bernardes. Reginaldo Aparecido Crisostomo. Relator: Desembargador Milton Carvalho. São Paulo, SP, 30 de agosto de 2016.Tjsp. São Paulo, 30 ago. 2016. Disponível em: <http://tj-p.jusbrasil. com.br/ jurisprudencia/390359628 /agravo-de-instrumento-ai21552061720168260000-sp-2155206-1720168260000/inteiro-teor390359645>. Acesso em: 21 out. 2016.

BRASIL. Tribunal de Justiça de São Paulo. Ementa no 2016.0000641614. Igreja Universal do Reino de Deus. Martha Haddad e Antonio Luiz de Magalhães. Relator: Desembargador Gomes Varejão. São Paulo, SP, 02 de setembro de 2016. Disponivel

em: <https://esaj.tjsp.jus.br/cjsg/getArquivo.do?cdAcordao $=9768069 \&$ cdForo $=0 \& v \mathrm{VIC}$ aptcha=yujnq $>$. Acesso em: 10 out. 2016.

BRASIL. Tribunal Superior do Trabalho. Decisão no 68-02.2013.5.23.0107. BRASIL FOODS S.A. - BRF. JOEZINO TOMÉ DA COSTA. Relator: Ministra DELAÍDE MIRANDA ARANTES. Brasilia, DF, 20 de outubro de 2014. Tst - Agravo de Instrumento em Recurso de Revista. Brasilia, 20 out. 2014. Disponível em: http://tst.jusbrasil.com.br/jurisprudencia/147355634/agravo-de-instrumentoem-recurso-de-revista-airr-680220135230107/inteiro-teor-147355690>. Acesso em: 20 out. 2016.

BRASIL. Tribunal de Justiça. Recurso Civil no 71002781334. Relator: Dr. Eduardo Kraemer. Porto Alegre, RS, 14 de julho de 2011. Tjrs. Porto Alegre, 14 jul. 2011. Disponível em: <http://tj-rs.jusbrasil.com.br/jurisprudencia/20114664/recursocivel-71002781334-rs/inteiro-teor-20114665>. Acesso em: 20 out. 2016.

BRASIL. Constituição (1941). Decreto Lei no 3688, de 03 de outubro de 1941. Lei das Contravenções Penais. Rio de Janeiro, RJ, 03 out. 1941. Disponível em: <http://www.planalto.gov.br/ccivil_03/decreto-lei/Del3688.htm>. Acesso em: 20 out. 2016. 
SILVA, Leonardo dos Santos; SIMINI, Danilo Garnica. Liberdade de culto e seus eventuais excessos: o exemplo da cidade de Ituverava/SP. Revista Eletrônica Direito e Política, Programa de PósGraduação Stricto Sensu em Ciência Jurídica da UNIVALI, Itajaí, v.12, n.3, $3^{\circ}$ quadrimestre de 2017. Disponível em: www.univali.br/direitoepolitica - ISSN 1980-7791

BRASIL. Constituição (1998). Lei no 9.605, de 12 de fevereiro de 1998. Dispõe Sobre As Sanções Penais e Administrativas Derivadas de Condutas e Atividades Lesivas Ao Meio Ambiente, e Dá Outras Providências.. Brasilia, DF, 12 fev. $1998 . \quad$ Disponível <http://www.planalto.gov.br/ccivil_03/leis/L9605.htm>. Acesso em: 20 out. 2016.

BRASIL. Constituição (1988). Lei no 1, de 05 de outubro de 1988. Constituição da República Federativa do Brasil de 1988. Disponível em: <http://www.planalto.gov.br/ccivil_03/constituicao/constituicaocompilado.htm>. Acesso em: 20 out. 2016.

BRASIL. Constituição (2002). Lei no 10406, de 10 de janeiro de 2002. Institui o Código Civil.. Brasília, DF, 10 jan. 2002. Disponível em: <http://www.planalto.gov.br/ccivil_03/leis/2002/L10406.htm>. Acesso em: 20 out. 2016.

BRASIL. Constituição (1985). Lei no 7347, de 24 de julho de 1985. Disciplina A Ação Civil Pública de Responsabilidade Por Danos Causados Ao Meioambiente, Ao Consumidor, A Bens e Direitos de Valor Artístico, Estético, Histórico, Turístico e Paisagístico (vetado) e Dá Outras Providências.. Brasilia, DF, 24 jul. $1985 . \quad$ Disponível em: <http://www.planalto.gov.br/ccivil_03/leis/L7347orig.htm>. Acesso em: 20 out. 2016.

BRASIL. Lei Complementar no 003/2006, de 02 de outubro de 2006. Institui 0 Código de Posturas no Município de Ituverava e Dá Outras Providências. Ituverava, SP, 02 out. 2006.2 Disponível em: <http://www.ituverava.sp.gov.br/admin/arquivo/24-09-2013-12-0707postura_lei.pdf>. Acesso em: 20 out. 2016.

BRASIL. Lei no 4.161, de 05 de julho de 2013. Ruídos Urbanos e Proteção Ao Bem Estar e do Sossego Público. Ituverava, SP, 05 jul. 2013.

BRASIL. Tribunal Regional do Trabalho. Ementa no 000054081.2015.5.23.0026. SIRLEY DA SILVA CRUZ. JBS/SA. Relator: DESEMBARGADOR EDSON BUENO DE SOUZA. Disponível em: <http://www.jusbrasil.com.br/diarios/documentos/320912508/andamento-doprocesso-n-0000540-8120155230026-ro-05-04-2016-do-trt-23>. Acesso em: 18 nov. 2016.

DINIZ, Maria Helena. Curso de Direito Civil: 7. Responsabilidade Civil. 26. ed. São Paulo: Saraiva, 2012. 146 p

GAGLIANO, Pablo Stolze; P. FILHO, Rodolfo. Novo curso de Direito Civil: Direito de Familia. 6. ed. São Paulo: Saraiva, 2011.

MÉDICI, Sergio de Oliveira, Contravenções Penais. Bauru/SP: Javoli, 1988 
SILVA, Leonardo dos Santos; SIMINI, Danilo Garnica. Liberdade de culto e seus eventuais excessos: o exemplo da cidade de Ituverava/SP. Revista Eletrônica Direito e Política, Programa de PósGraduação Stricto Sensu em Ciência Jurídica da UNIVALI, Itajaí, v.12, n.3, $3^{\circ}$ quadrimestre de 2017. Disponível em: www.univali.br/direitoepolitica - ISSN 1980-7791

SILVA, José Afonso da. Comentário contextual à Constituição. 4. ed. São Paulo: Malheiros, 2007.

VENOSA, Silvio de Salvo. Direito Civil: Responsabilidade Civil. 15. ed. São Paulo: Atlas, 2015.

Submetido em: maio de 2017

Aprovado em: dezembro de 2017 